\title{
Hypothesis
}

\section{Mechanisms of Molecular Mimicry Involving the Microbiota in Neurodegeneration}

\author{
Robert P. Friedland* \\ Department of Neurology, University of Louisville School of Medicine, Louisville, KY, USA
}

Accepted 17 December 2014

\begin{abstract}
The concept of molecular mimicry was established to explain commonalities of structure which developed in response to evolutionary pressures. Most examples of molecular mimicry in medicine have involved homologies of primary protein structure which cause disease. Molecular mimicry can be expanded beyond amino acid sequence to include microRNA and proteomic effects which are either pathogenic or salutogenic (beneficial) in regard to Parkinson's disease, Alzheimer's disease, and related disorders. Viruses of animal or plant origin may mimic nucleotide sequences of microRNAs and influence protein expression. Both Parkinson's and Alzheimer's diseases involve the formation of transmissible self-propagating prion-like proteins. However, the initiating factors responsible for creation of these misfolded nucleating factors are unknown. Amyloid patterns of protein folding are highly conserved through evolution and are widely distributed in the world. Similarities of tertiary protein structure may be involved in the creation of these prion-like agents through molecular mimicry. Cross-seeding of amyloid misfolding, altered proteostasis, and oxidative stress may be induced by amyloid proteins residing in bacteria in our microbiota in the gut and in the diet. Pathways of molecular mimicry induced processes induced by bacterial amyloid in neurodegeneration may involve TLR 2/1, CD14, and $\mathrm{NF} \kappa \mathrm{B}$, among others. Furthermore, priming of the innate immune system by the microbiota may enhance the inflammatory response to cerebral amyloids (such as amyloid- $\beta$ and $\alpha$-synuclein). This paper describes the specific molecular pathways of these cross-seeding and neuroinflammatory processes. Evolutionary conservation of proteins provides the opportunity for conserved sequences and structures to influence neurological disease through molecular mimicry.
\end{abstract}

Keywords: Alzheimer's disease, amyloid, bacterial amyloid, metagenome, microbiota, neurodegenerative diseases, neuroinflammation, oxidative stress, Parkinson's disease

\section{INTRODUCTION}

The concept of mimicry was offered initially by Bates to describe similarity of structure in Lepidoptera developed as a result of evolutionary pressures [1]. Molecular mimicry (MM) was proposed by Damian who pointed out that natural selection has led parasites to mimic antigens of their hosts [2]. That is, the sharing of antigens between microbe and host may help the microbe avoid immune detection [2].

${ }^{*}$ Correspondence to: Robert P. Friedland, MD, Department of Neurology, University of Louisville School of Medicine, Louisville, Kentucky 40202, USA. Tel.: +1 502852 2871; E-mail: robert. friedland@louisville.edu.
Evolutionarily conserved epitopes can clearly be involved in a pathogenic manner in MM, such as in autoimmune disorders, as well as in salutogenic (health-giving) mechanisms [3]. The protection against smallpox (variola) provided by exposure to vaccinia (derived from cowpox) is an example of this salutogenic influence [3]. In autoimmunity it is well recognized that similarity between host and foreign antigens can lead to humoral as well as cell mediated antibody responses targeting foreign antigens that cause disease through influences on host proteins. The nature of the structural homology in MM has usually been related to the primary structure of proteins (amino acid sequence). It has been proposed that MM may be 
responsible for ulcerative colitis because of similarity of primary structures between gut epithelial cells and bacteria. The foreign antigen eliciting MM has most often been reported to be present in bacteria or animal viruses. The concept of MM can be expanded to include the ability of foreign proteins from plant viruses to induce autoimmunity [4-6]. Plant proteins in food may also elicit MM and cause demyelination [7]. Furthermore, we have proposed that microRNA mechanisms may be involved in MM [8]. Finally, I propose that bacterial proteins may elicit cross-seeded misfolding, inflammation and oxidative stress, and cellular toxicity in the neurodegenerative conformational disorders, initiating or otherwise influencing the development of Parkinson's disease (PD), Alzheimer's disease (AD), and related conditions.

MM may develop when there is an evolutionary desirable advantage to the similarity (as described by Bates) [1]. The chance similarity of protein structures, as is the case for rheumatic heart disease, may also result in MM-induced processes [9]. The concepts and mechanisms of MM have recently been delineated by Oldstone, who notes that only 5-6 amino acids are needed for generation of a monoclonal antibody response [10]. Proteins that share amino acid sequences or conformation may elicit $\mathrm{MM}$ as long as they are not identical (if they are identical they will not be recognized as foreign and there will be immune tolerance) [10]. Therefore, the opportunity arises for evolutionarily conserved proteins, as well as proteins that contain homologies entirely by chance, to be involved in MM. These homologies creating the opportunity for MM may involve primary, secondary, or tertiary protein structures or the nucleotide sequence of RNA in animal or plant viruses, bacteria, or food (See Table 1). Examples of ways in which these mechanisms of MM may influence the nervous system will now be reviewed.

\section{MOLECULAR MIMICRY INVOLVING PRIMARY PROTEIN STRUCTURE}

\section{Potato virus $Y$ and $A D$}

Following the discovery that immunization with amyloid- $\beta(A \beta)$ protein causes improvement in the biological and pathological feature of $A \beta$ deposition in transgenic animals by Schenk and colleagues in 1999, a wide range of animal and human studies have been devoted to the immunological features of $\mathrm{AD}$ [11]. It is clear that immune responses targeting the $A \beta$ protein have a profound biological effect on $A \beta$
Table 1

Molecular mimicry may develop in response to similarities in structure at these levels

\begin{tabular}{lll}
\hline Level & Example & REF \\
\hline Primary protein structure & Rheumatic fever & {$[9]$} \\
Nucleotide sequence & MicroRNAs & {$[8]$} \\
Tertiary protein & Cross-seeding of & {$[64,65]$} \\
structure & protein misfolding & \\
\hline
\end{tabular}

deposition in animals and humans [11]. However, it is not yet known whether this effect can be developed for therapeutic use. This work led to the suggestion that antibodies targeting the $A \beta$ protein in healthy people may be protective [4]. Studies of anti-A $\beta$ antibodies in $\mathrm{AD}$ and healthy controls have shown that levels may be increased, decreased, or unchanged $[4,12]$. These studies need to account for the influence of circulating A $\beta$ antibody levels on antibody assays [12]. Protective catalytic $\operatorname{IgM}$ antibodies efficiently cleaving the $A \beta$ protein have also been reported [13]. Despite conflicting studies, it has been demonstrated that many people produce antibodies targeting $A \beta$. The factors responsible for development of anti-A $\beta$ antibodies and their role in $\mathrm{AD}$ remain unclear.

For these reasons, we performed a BLAST search (Basic Local Alignment Search Tool, NCBI, National Library of Medicine, US) and found that significant homology exists between the human $A \beta$ protein and the nuclear inclusion $\mathrm{B}$ protein of potato virus $\mathrm{Y}$ [4]. We observed that mice inoculated with potato leaf infected with potato virus $\mathrm{Y}$ develop antibodies that bind to human and animal $\mathrm{A} \beta$ [4]. The question remains if exposure to potato virus $\mathrm{Y}$ may elicit antibodies that bind to $A \beta$ and enhance clearance from the brain, lowering the risk of $\mathrm{AD}$.

Plant viruses are widespread in the environment and have major economic impact on agriculture. Live pepper viruses are found in sauces made from Tabasco peppers (Capsicumfrutescens). Although plant viruses are not believed to replicate in any animal host, it has been demonstrated that they survive inactivation in the gut, are taken up through the intestinal barrier, and circulate through the body with a wide distribution [14]. The pepper mild mottle virus is highly abundant in human stool and can be acquired through oral intake. It is of interest that plant viruses evolved in part because of their capacity to tolerate survival in animal hosts, as they are transmitted through insect vectors. These interactions may be pathogenic if the induced antibodies developed in response to exposure to a plant virus cause disease, or salutogenic if the antibodies are protective, as in the proposed case of potato virus $\mathrm{Y}$ in $\mathrm{AD}$ 
[4]. The possibility that antibodies to plant viruses are involved in human diseases has not been previously considered.

\section{Tobacco mosaic virus (TMV) and PD}

Many studies have shown that exposure to tobacco products as well as to solanaceous plants in the diet are protective against the development of PD [5, 6]. Although there are many theories to explain these effects the mechanisms are unclear. TMV is known to infect over 175 species of plants, especially those of the Solanaceae family and is the best studied plant virus. We found that all of 60 healthy controls have anti-TMV antibodies, mostly IgG, with higher titers in smokers than nonsmokers [5]. An intriguing homology of 6 identical amino acids was found between the TMV primary structure (36-41) and the sequence of the important mitochondrial membrane protein translocase of the outer mitochondrial membrane (TOMM 40L) (60-65), and mitochondrial dysfunction has been well documented in PD [5]. Further studies of antiTMV antibodies are needed.

\section{Aquaporins in brain and plants}

The demyelinating disease neuromyelitis optica (NMO) is associated with antibodies to the astroglial water channel protein aquaporin 4 (AQP4). Water channels are clearly important for life in both plant and animals and aquaporins are highly conserved in animals and plants. We compared human AQP4 to plant and bacterial proteins to see if homologous structures preserved through evolution may be found that could explain the source of autoimmunity in NMO. We found that a sequence of plant aquaporin (maize ZmTIP4-1, 196-221) has high similarity to a known loop E epitope of human anti-AQP4 IgG antibodies from NMO patients (AQP4 207-232) (20 out of 26 amino acids identical) [7]. Sera from NMO patients showed reactivity to plant peptides as well as to plant tissue [7]. The opportunities for human autoimmune disease to be initiated through MM by exposure to plant aquaporins have not been considered.

\section{MOLECULAR MIMICRY INVOLVING MICRORNA MECHANISMS}

A further consideration regarding primary sequence homology concerns the consideration that plant viruses may be processed in the body through mechanisms involving microRNAs. RNAs are "the most functionally diverse biological macromolecule" and have complex three-dimensional structures [15]. MicroRNAs are small 18-22 nucleotide long noncoding molecules that regulate protein synthesis. It is estimated that microRNA pathways are involved in the regulation of gene expression for at least a third of all human brain proteins [16]. Humans are exposed to many plant viruses which contain RNAs, establishing the potential for MM to impact health (see Table 2). As noted above, plant viruses are taken up through the gut and well distributed. We considered the possibility that homology of nucleotide sequence in plant viral RNA could lead to the production of microRNAs, which influence protein expression in animal hosts. This process has been already demonstrated with animal viruses: RNA from herpes virus saimiri binds to and initiates the degradation of human MIR-27, resulting in enhanced infection [17, 18]. We found that several plant viruses contain nucleotide sequences which are significantly homologous to human microRNA sequences [8]. In several cases, the plant viruses contain nucleotide sequences which exactly match the seed sequence of human microRNAs, in either parallel or anti-parallel directions [8]. Plant viral RNA may also interact with RNA binding proteins with influences on protein expression. There is also the opportunity for the RNA of plant viruses to mimic long non-coding RNAs and other RNA species. Furthermore, the influence of microRNAs from plants consumed in the diet on lipid metabolism has been demonstrated in mammals [19]. The consequences of these cross-kingdom sequence similarities need to be further explored.

Table 2

\begin{tabular}{ll}
\hline Agents inducing molecular mimicry & REF \\
\hline Bacteria* $^{*}$ & {$[9,44,56]$} \\
Animal viruses* & {$[3]$} \\
Plant viruses* & {$[4,5,15]$} \\
Amyloids proteins in food & {$[50,56]$} \\
Bacteria that make amyloid proteins** & \\
\hline
\end{tabular}

Bacillus subtilis

Escherichia coli

Klebsiella pneumoniae

Mycobacterium tuberculosis

Salmonella enterica

Salmonella typhimurium

Staphlococcus aureus

Streptococcus mutans, coelicolor

Xanthomonas axonopodis

*Exogenous as well as endogenous (found in the microbiota). ${ }^{* *}$ The list is incomplete. Genes for producing amyloids are also found in these phylum of bacteria: Actinobacteria, Bacteroidetes, Chloroflexi, Firmicutes, Proteoabacter, Thermodesulfobacteria [46, 47, 49, 64]. 


\section{MOLECULAR MIMICRY INVOLVING TERTIARY STRUCTURE}

\section{Proteomics}

The neurodegenerative disorders $\mathrm{PD}, \mathrm{AD}$, amyotrophic lateral sclerosis, frontotemporal lobar degeneration, Lewy body dementia, and progressive supranuclear palsy are all of sporadic origin in 90-99\% of cases and are all associated with amyloid misfolding of neuronal proteins in the central nervous system. In the sporadic forms of each disorder, the factors responsible for the initiation of protein misfolding are unknown. Recently it has been shown that the disease associated proteins $\alpha$-synuclein (AS), found in PD, and $\mathrm{A} \beta$, found in $\mathrm{AD}$, as well as tau, are capable of transmission of misfolding from one brain region to another and from an animal or human to a susceptible host [20, 21] (for review, see [22, 23]). Amyloid misfolding involving oligomeric species, a hallmark of these neurodegenerative diseases, is believed to be a main cause of neuronal death. I propose that the misfolding of the neuronal proteins found in $\mathrm{PD}, \mathrm{AD}$, and related disorders is triggered by $\mathrm{MM}$ induced templated cross-seeding, similar to the mechanism proposed for misfolding in the prion diseases.

PD is characterized by accumulation of aggregated and phosphorylated AS in Lewy bodies and Lewy neurites [24-26]. Aggregated AS is a form of amyloid found in many brain regions as well as in neurons in the myenteric plexus of the gut wall in PD patients, and in aged rats $[24,25]$. AS, as well as $A \beta$, tau, FUS, and TDP43 can induce autocatalytic protein misfolding following a rate limiting nucleation event, which spreads within the central nervous system to cause disease [23, 27, 28]. The mechanism of this self-templated nucleation dependent spreading of amyloid misfolding is analogous to that of the prion disorders, such as Creutzfeldt Jakob disease (CJD), bovine spongiform encephalopathy, and others $[23,28]$. The spreading in the brain of misfolded AS and tau appears to be along neuronal connections through axonal membranes utilizing a prion-like cell-to-cell spread with neuronal connectivity, not proximity, being critical [29-31]. This work has led to the proposal that the amyloid proteins of the neurodegenerative disorders are prions [32]. Nonetheless, the source or origin of the misfolding in $\mathrm{PD}$ or $\mathrm{AD}$ is currently unknown. Prusiner has suggested that the initial event is the stochastic (random) misfolding of the prion-like protein [32]. This may not be the only mechanism of this critical misfolding. We must ask: can the misfolding be induced by endogenous or exogenous factors, and what is the initial trigger?

In the case of bovine spongiform encephalopathyinduced new variant CJD, the origin of the misfolding is known to come from ingested bovine spongiform encephalopathy prions, which cause prion transformation initially in gut neurons. The first brain region found to contain the scrapie prion in sheep is reported to be the dorsal motor nucleus of the vagus nerve in the medulla [33]. The dorsal motor nucleus of the vagus contains the neuronal cell bodies of the vagus nerve fibers which innervate the gut. Most remarkably, this is also one of the first brain regions to contain misfolded AS in PD $[24,25,34]$. Furthermore, myenteric neurons in the gut wall contain AS deposits in PD. These findings suggest that the origin of protein misfolding in PD may reside in the gut.

Another site of initiation of protein misfolding may be the olfactory epithelium. Olfactory impairment and anosmia have been associated with aging in humans as well as with several neurodegenerative disorders including $\mathrm{PD}, \mathrm{AD}$, and others. The molecular mechanisms underlying olfactory decline in these disorders remain unclear. There is early involvement of the olfactory system in PD and AD and the olfactory cortex is structurally linked to the site of main PD pathology, the substantia nigra [35, 36]. Olfactory pathology has been reported to predict Braak staging in AD [37]. Prion seeding of the nose has also been recently found in CJD [38]. It is important to note that there is a close spatial relationship between the olfactory receptors (which are processes of neurons from the brain) and bacteria present in the nose.

If the protein misfolding problem in $\mathrm{PD}$ and $\mathrm{AD}$ originates in the gut and/or nose, which inducing factors may be responsible? There has been a great expansion of interest and knowledge about the microbial metagenome. The recent human microbiome project has brought renewed attention to the resident bacterial population of the human body (Human Microbiome Project Consortium) [39]. The human microbiome refers to the collective DNA sequences of all the organisms residing on or in a person. It is estimated that there are $10 \mathrm{X}$ more cells and $130 \mathrm{X}$ more DNA in the metagenome than in our own bodies $[40,41]$. The volume of gut bacteria is estimated at $250 \mathrm{ml}$ in adults, with $\sim 10^{11}$ cells per $\mathrm{ml}$ of colonic contents [42]. The collective organisms in the gut (which includes the nose, oropharynx, esophagus, stomach, and intestines) whose DNA contributes to the metagenome is referred to as the microbiota. These organisms residing on the skin, in the mouth 
and gut and other regions have been shown to be involved in diabetes mellitus, hypertension, atherosclerosis, coronary heart disease, ankylosing spondylitis, liver disorders, and other conditions [43, 44]. Although our evolution has occurred simultaneously with the evolution of our microbiota, the role of these organisms on brain health has not been addressed.

Changes in the microbiota have been demonstrated in aging, with reduced diversity of organisms linked to residential community, reduced dietary diversity, frailty, and other health outcomes [45]. Other influences on the microbiota in the aged include medications, impaired gastrointestinal motility, impaired gut-blood barrier, and decreased immune function. Declining production of chaperones necessary for proper protein folding may also be involved. These age-related changes in the gut microbiota may all be linked to the age-relatedness of the neurodegenerations.

Bacteria found in the human microbiota have been shown to produce extracellular amyloid proteins [46-48]. Bacterial amyloid proteins are adaptive and enhance adhesion, aggregation, biofilm formation, tissue invasion, colonization, and infectivity [46]. The formation of amyloid by proteins has been considered for decades to be an entirely pathological event. However, recently it has been shown that functional amyloids are found in yeast, bacteria, rodents, and humans [47, 49]. The ability to form amyloid folds appears to be a highly conserved pathway with adaptive value for information transfer and structural dynamics [49]. The prion forming ability of proteins in yeast and fungi is believed to be as much as 1 billion years old [50]. It has been proposed that prion formation in the brain is involved in memory storage [51]. The extracellular amyloid protein called curli produced by $E$. coli and $S$. typhimurium enhances colonization and biofilm development $[46,52]$. Curli fibers bind Congo red and host proteins and have well-developed mechanisms of regulated expression [46]. Curli fibers have been shown to mediate internalization into host cells and contain short peptide repeats similar to those of yeast and animal prions [53]. While bacterial amyloids are now well documented, there have been no investigations of their role in brain disease [54]. I propose two mechanisms by which amyloid from bacteria may induce or influence human neurodegeneration: 1) protein misfolding and 2) induction of neuroinflammation and oxidative stress (see Table 3).

Despite the considerable evidence that many of the bacterial species residing in the body make amyloid proteins there has been little work on the presence of bacterial amyloid in the gut. (See Table 2) [52, 55]. The bacterial protein curli from $E$. coli has been found in the gastrointestinal tract of humans [52]. Streptococcus mutans is a widespread oral symbiont which makes an amyloid protein and has been linked to hemorrhagic stroke $[48,55]$. Also, the ability of amyloid in the gut to induce protein misfolding and systemic disease has been demonstrated in systemic amyloidosis (see "Amyloidogenic potential of foie gras" [56]). Xing et al. showed that orally delivered seeds composed of homologous peptide caused amyloid deposits in a mouse model of apolipoprotein A-ll amyloidosis [57]. Proteins from gut bacteria may gain access to neurons in the myenteric plexus because of the sampling of gut contents by epithelial microfold (M) cells as well as dendritic cells which deliver antigens to immune cells in Peyer's patches [58, 59]. It has also been shown that prions are taken up by follicle-associated epithelial cells in the gut, and then delivered by macrophages and dendritic cells to enteric nerves [60]. The only barrier in the nose for entry of molecules into the brain is the plasma membrane of olfactory neurons, which are exposed to air in the roof of the nose. Little et al. observed that intranasal inoculation of Chlamydia pneumonia in BALB/c nontransgenic mice caused amyloid deposits in the brain and an elevated inflammatory response [61]. Furthermore, it has been shown that olfactory ensheathing cells recognize and endocytose bacteria [62, 63]. The relationships between exposure to bacterial amyloids to misfolding of AS, $\mathrm{A} \beta$, and other proteins related to neurodegeneration have not been investigated.

How might bacterial amyloid proteins influence neurodegenerative processes? The transmission of misfolding from one molecule of a protein to another molecule of the same protein was proposed originally by Prusiner as the mechanism for the prion disorders

Table 3

\begin{tabular}{lll}
\hline Proposed mechanisms of MM in ND & Molecular Pathways & REF \\
\hline Induction of protective anti-A $\beta$ antibodies & epitope homology & {$[4]$} \\
Cross-seeding of protein misfolding & prion transmission & {$[22,23,28,64]$} \\
Neuroinflammation and oxidative stress & TLR2/1, CD14, NF $\kappa$ B, iNOS & {$[79,83,88]$} \\
\hline
\end{tabular}

MM, molecular mimicry; ND, neurodegeneration; $\mathrm{A} \beta$, amyloid- $\beta$. 
(as shown by the conversion of $\operatorname{PrP}^{\mathrm{c}}$ to $\mathrm{PrP}^{\mathrm{sc}}$ ) [32]. It has also been shown that one misfolded molecule may elicit the misfolding of a different molecule (crossseeding: an endogenous or exogenous protein may induce beta sheet misfolding of a host protein with a different primary structure). A wide range of environmental amyloid fibrils has been shown to cause cross-seeding of $A \beta$ aggregation in vitro $[64,65]$. Lee's group has shown that AS aggregates seed aggregation of tau [22]. Morales and associates have shown that prion inoculations in AD model transgenic mice cause the acceleration of both disorders [65]. I propose that cross-seeding of the neurodegenerative disorder proteins may be induced by environmental amyloids such as those produced by bacteria. The seed may initiate changes in proteostasis (misfolding) or accelerate the important lag phase of nucleation.

What aspects of cross-seeding may explain the complex phenotypic heterogeneity of the neurodegenerative disorders? Strains have been well recognized in prions as responsible for the unique characteristics of potency, incubation time, host specificity, and disease phenotype [32]. The 3D physical nature of the amyloid fold, which is stable and propagated in vivo, is thought to be responsible for these features of a prion strain. It has been established that a single infectious prion protein can become misfolded into several different conformations, resulting in strains [66]. Recently it has been reported that the disease-associated amyloids AS and $A \beta$ also show the features of strains with unique fibril structures which determine the structure of associated pathologies [22, 67, 68]. Hartman et al. have documented the ability of bacterial amyloids to induce cross-seeding, including interactions with proteins of dissimilar sequences [64]. The unique structures of prion strains may be predetermined by the structure of the bacterial (or other) amyloid which induced the initial cross-seeding misfolding event.

Furthermore, the possibility that bacterial amyloids may induce cross-seeding of endogenous proteins such as $\mathrm{A} \beta, \mathrm{AS}$, tau, and others is supported by the observation that the bacterial amyloid protein curli is recognized by the conformation specific anti-A $\beta$ oligomer antibody A11, as reported by Glabe and colleagues $[69,70]$. This work suggests that there are soluble oligomers that have a common generic structure. Amyloids have also been found in dietary items, including milk, meat, maize, berries, fungi, and organ products, as well as various other plants $[71,72]$. VillarPique has suggested that the production of amyloid conformations in genetically-modified plants deserves investigation [73].

\section{NEUROINFLAMMATION AND OXIDATIVE TOXICITY}

The large surface area of the oral/nasal cavities and gut epithelial layer is the dominant interface for interactions between bacteria and our own cells. It is necessary for the maintenance of homeostasis that the immune system be aware of the gut bacterial contents [74]. The gut is the largest immune organ in the body and the huge antigenic load contained within would be of great potential danger if it was not subject to continuous surveillance [74]. It has been recently demonstrated that the microbiota have a strong influence on the immune system. The production of anti-inflammatory Treg cells may be enhanced by addition of "rationally selected" Clostridia strains [75]. Furthermore it has been proposed that the immune system undergoes "peripheral education" by the intestinal organisms, as germ-free mice have deficient immunity [76]. Surveillance of gut antigens is enhanced by the ability of immune cells (monocytes, macrophages, dendritic cells, and some epithelial cells) to readily recognize pathogen associated molecular patterns (PAMPS) [77]. Bacterial amyloid is recognized as a PAMP and causes activation of toll-like receptor-2 (TLR2) and other important mediators of inflammation including $\mathrm{NF} \kappa \mathrm{B}$, a master-regulatory molecule of inflammation, as well as TLR1 and CD14 [78, 79]. TLRs are expressed on immune cells as well as neurons and influence the production of a wide array of inflammatory molecules including cytokines and chemokines [80]. A wide array of molecules activate TLR2, including peptidoglycan and lipoteichoic acid as well as bacterial amyloid, AS, and $\mathrm{A} \beta$ [77].

Large numbers of $\mathrm{T}$ cells are found in the gut wall. These cells circulate widely and may enter the brain [81]. The gut is extensively innervated, including fibers supplying the smooth muscle, epithelium, blood vessels, and Peyer's patches. Immune molecules in the blood may reach the brain (either directly or indirectly) through several mechanisms: active transport across the blood-brain barrier, signaling in the intestinal lumen and propagation of secondary factors into the brain; spread to brain through the circumventricular organs, or signaling via nerves, such as the vagus [80-82]. The idea that inflammation in the brain may be linked to bacterial amyloid has been proposed by Trudler et al., who suggested that cerebral amyloid may mimic viral or bacterial infection resulting in glial cell activation through TLRs [83]. TLR2 activation has also been reported to cause Notch1 upregulation, which may enhance processes leading to AD [84]. 
Beginning with the pioneering work of McGeer and colleagues, it has been established that there is sterile inflammation in the brain in the neurodegenerative disorders $[85,86]$. Neuroinflammation has been documented in PD, with a specific upregulation of TLR2 signaling and activation of microglia [87]. Richard et al. reported that TLR2 assists in clearance of $A \beta$ from the brain in transgenic mice [88]. Increased expression of TLR2 (as well as TLR4) has also been found in peripheral blood mononuclear cells in AD $[19,82]$. TLR signaling has also been found to involve microglial cells in the central nervous system, especially TLR2 [83]. Furthermore, TLR2 has been shown to be important for the regulation of intestinal barrier integrity. Activation of innate immunity can also influence goblet cell mucus secretion and thereby the gut-blood barrier [89]. Another important molecule of the innate immune system response is CD14, which is involved in the activation of the TLR2/TLR1 complex in response to lipopolysaccharides or bacterial amyloid, as well as the immune reaction to pathogens $[90,91]$. Peripheral inflammatory processes have been shown to influence several forms of neurodegeneration [80, 92]. Bodea and colleagues reported that peripherally-induced inflammation activates the microglial complement pathway to damage dopaminergic neurons in mice [93].

TLR2/1 activation and CD14 expression may lead to upregulation of $\mathrm{NF} \kappa \mathrm{B}$ expression and induction of nitric oxide synthase, with resultant inflammation and oxidative toxicity [79]. Oxidative toxicity with production of free oxygen and nitrogen radicals has been implicated in all neurodegenerative disorders [94]. It has been proposed by Perry, Smith, and colleagues that oxidative toxicity is a primary process in $\mathrm{AD}$ with $\mathrm{A} \beta$ deposition occurring as a response to free radical production [95].

The potential role of the microbiota in autoimmunity is well illustrated by ankylosing spondylitis, which is associated with HLA B27 and Klebsiella pneumonia [10]. It has been reported that there is a 6 amino acid homology between HLA B27 and Klebsiella pneumoniae in regions exposed to the cell surface [10]. It has been proposed that ankylosing spondylitis occurs because of this MM, in which cross-reactive antibodies targeting Klebsiella pneumoniae residing in the colon attack self-antigens and cause inflammation in joints in persons with the HLA B27 genotype [96].

The important role of inflammation in neurodegeneration is also supported by the recent finding of rare genetic risk factors for $\mathrm{AD}, \mathrm{FTD}$, and $\mathrm{PD}$ that influence innate immunity: TREM2 (Triggering
Receptor Expressed on Myeloid cells 2) and clusterin [97, 98]. TREM2 is widely expressed on circulating cells, microglia, and plaque associate myeloid cells. TREM2 stimulates phagocytosis, suppresses cytokine production and inflammation, and inhibits TLR signaling in peripheral macrophages and dendritic cells. Another component of the innate immune system is clusterin, which has also been found to be genetically linked to AD. Clusterin is expressed in M cells and the dendritic cells in Peyer's patches in the human gut [99].

I propose that inflammation as well as oxidative toxicity in PD and AD may be enhanced by exposure to bacterial amyloids as both bacterial amyloids, and the amyloid proteins $\mathrm{A} \beta$ and $\mathrm{AS}$ are recognized as PAMPs through a TLR 2 mediated pathway, leading to inflammation and oxidative toxicity. Immune cells primed by exposure to bacterial amyloid may be more responsive to the presence of $\mathrm{A} \beta$ or AS in the brain. These immune cells include both brain resident microglia as well as circulating macrophages that have access to the brain [81]. Immune activation produced by the microbiota may also delay elimination of important brain proteins such as $A \beta$, which are cleared by perivascular drainage pathways [100, 101].

Several groups have found that many older persons with $A \beta$ deposits do not have dementia [102]. Akiyama and colleagues have observed that nondemented persons who have $A \beta$ deposits demonstrate less inflammation than the $A \beta$ deposits of persons with dementia [86]. Priming of microglia (as described by Perry, Holmes, and colleagues) and enhancement of related immune responses to $\mathrm{A} \beta, \mathrm{AS}$, and other misfolded proteins produced by bacterial amyloid may thus enhance dementia development [92, 103].

The role that inflammation plays in neurodegeneration is not well understood. It is curious to consider that the mechanisms proposed here may work in varying directions. Inflammation in the neurodegenerative disorders is limited to microgial/astroglial activation, complement, cytokine expression, and associated oxidative stress. The reason why there is not lymphocyte or macrophage accumulation is not clear (for review, see [104]). Immune responses to bacterial amyloid may be pathogenic if they lead to oxidative stress and damaging cytokines. Immune responses to bacterial amyloids may be protective if they enhance clearance of toxic oligomers. A beneficial response to inflammation in a mouse model of $\mathrm{AD}$ has been reported [105]. It has been observed that complement $\mathrm{C} 3$ deficiency reduces microglial priming and enhances plaque deposition, suggesting that the 
complement mediated component of the immune response is beneficial [106]. Also, a beneficial effect of $A \beta$ reactive T cells in mice has been observed [107] and $\mathrm{Th} 2$ based immune responses have been shown to be salutogenic in AD model mice [108].

Amyloids of exogenous origin may occupy chaperones, influencing the opportunity for misfolding to occur. It is also worth considering the observation that inhibition of fibrillization may lead to greater seeding potential and more toxic $A \beta$ oligomers $[109,110]$. Influences of the microbiota on clearance of misfolded proteins should also be considered.

It appears oversimplified to consider the potential role of proteomic or immune interactions in these disorders to be either entirely pathogenic or protective.

\section{GENETIC AND EPIDEMIOLOGICAL CONSIDERATIONS}

Interactions of genes and environment are, of course, critical factors in genesis of all diseases. The influence of the microbiota on health is certainly influenced by genes, although this matter has not been well studied. The interaction of environmental factors, human genes, and the gut is illustrated by variant CJD. Cases of CJD identified so far exclusively have the methionine homozygous (MM) genotype at codon 129 of the PRNP gene, and people who are heterozygotes (MV) or valine homozygotes (VV), are resistant [32]. Apolipoprotein E (ApoE) is the most important genetic risk factor for $\mathrm{AD}$. The $\varepsilon 4$ allele of ApoE has been shown recently to also increase the risk for dementia in synucleinopathies, including PD [111]. Although several mechanisms for these effects have been proposed, it is not clear which are responsible. ApoE, as a lipid-handling gene, influences bile acid secretion in humans and mucin secretion in murine lung, and has immunomodulatory effects [112-115]. Bile is known to influence bacterial growth in the gut and the gut barrier is comprised, in part, by layers of mucin. The relationship between ApoE genotype, gut bacteria, and the gut-blood barrier has not been addressed. The consideration that ApoE genotype may influence the microbiota to favor the development of organisms triggering misfolding should be investigated. Also, the micobiota is known to modulate the lipidome, and may influence production of plasma phospholipids (such as phosphatidylinositol and glycoursodeoxycholic acid) reported to be higher in AD sera [116].

It has been observed that $\mathrm{AD}$ is less common in subSaharan Africa and India than in Western countries, even when correcting for the effects of survival [117]. The reasons for this lower prevalence and incidence are not clear, and have been attributed to the higher level of lifetime physical activity, lower levels of fat consumption, and higher levels of fruit, vegetable, and fiber intake in developing countries. The possibility that dietary influences on microbiota consumption are responsible for these effects deserves consideration. In particular, dietary fiber enhances the growth of colonic bacteria that produce short chain fatty acids which have systemic anti-inflammatory effects [118], which may be protective against several disease processes. Furthermore, potatoes in developing countries are more likely than those in Western countries to be infected with potato virus Y, as industrial agriculture has developed the use of sterile seed potatoes. The influence of exposure to potato virus $\mathrm{Y}$ (or other plant viruses) on health has not been well explored.

\section{DISCUSSION}

This paper has reviewed ways in which human health may be influenced by conserved protein and nucleotide sequences and protein folding patterns. The view presented here describes how the interaction of humans with our external and internal microbial ecosystems may be determinants of neuronal health and disease.

Investigations of the mechanisms suggested here may have implications for the multiple neurodegenerative proteinopathies, as these disorders involve similar scenarios of transmissible protein misfolding, neuroinflammation, and oxidative stress of unclear origin (AD, $\mathrm{PD}$, frontotemporal lobar degeneration, amyotrophic lateral sclerosis, Lewy body dementia, CJD, cortical basal ganglionic degeneration, multiple system atrophy, progressive supranuclear palsy). Microglial activation through TLRs may be linked as well to CJD, HIV/AIDS, stroke, and multiple sclerosis. Inflammatory mechanisms and TLR2 are also involved in atherosclerosis [119]. Cerebrovascular changes have long been associated with $\mathrm{AD}$, including enhancement of cognitive changes, white matter lesions, cerebral amyloid angiopathy, and microbleeds. Microbiota in the naso-oropharynx may impact vascular inflammation and oxidative stress to influence these processes $[55,120]$. Nakano et al. have demonstrated the influence of oral bacteria on hemorrhagic stroke in humans [55].

An additional mechanism by which endogenous amyloids may influence health has been recently 
Table 4

Locations where microbiota-host interactions may influence health*

\begin{tabular}{ll}
\hline Body site & Site of influence \\
\hline Roof of nose & olfactory epithelium \\
Naso-oro-pharynx & vessels passing through and near sinuses going to brain \\
Mouth & olfactory epithelium, proximate brain vessels \\
Gut (stomach, small and large intestines) & myenteric neurons, autonomic nervous system, spinal cord and brain \\
\hline *Microbiota may also influence health through circulating pathways. &
\end{tabular}

demonstrated. Amyloids in human semen enhance infectivity of HIV and CMV [121, 122]. Several authors have proposed an important role for viral infection in late-life brain disorders. The influence of amyloids in the microbiota on viral diseases has not been considered.

\section{SUMMARY}

The neurodegenerative disorders all involve altered proteostasis and in most cases the agent initiating the misfolding is not known. The prominent pathology in enteric and olfactory neurons in PD suggests that the agent may be coming from the gut, including the oral/nasal/pharyngeal cavities. The opportunity for chronic exposure to foreign antigens in these regions is great. Functional amyloids are made by gut bacteria and may be the source of: 1) misfolding of neuronal proteins through cross-seeding and 2) activation of the innate immune system and priming of neuroinflammation. The unique structure of the foreign amyloid may induce specific misfolding patterns (strains) which may be responsible for the variety of phenotypes of the neurodegenerative disorders.

Similarities of nucleotide sequence and protein configuration that involve primary, secondary, or tertiary structure may influence health and disease involving immunological, miRNA, or proteomic mechanisms. Salutogenic processes may be enhanced through MM which may inhibit myriad disease processes. It is important to consider the extensive conservation of protein sequences and structures through evolution and the opportunities for human health to be affected by our interactions with plants, plant and animal viruses, prokaryotes, and other forms of life. The opportunities for cross-kingdom interactions (bacteria, plants, animals, and others) must be considered. The microbiota is a rich source of these interactions and the possibility of MM originating in the gut including the oral/nasal cavities is just beginning to be explored. Proteins with amyloid configurations are widespread in the environment because of their adaptive value [46, 53]. The possibility that bacterial or other nonhuman amyloid proteins themselves can function as prions in mammalian hosts deserves consideration.

More specifically, I propose that amyloid crossseeding in neurons is triggered by amyloid-containing bacteria in the nose and/or gut. The trigger for AS misfolding in PD may be from bacterial amyloids that influence the brain through the vagus and other nerves from the gut and/or directly through the roof of the nose to the olfactory cortex. The trigger for $\mathrm{A} \beta$ misfolding may also originate in the nose or gut (See Table 4). At the same time, bacterial and other exogenous amyloids may induce inflammation and oxidative stress through TLR-mediated pathways leading to enhanced immune responses to endogenous amyloids such as $\mathrm{AS}$ or $\mathrm{A} \beta$.

It would be desirable if the potential for crossseeding between two candidate proteins could be predicted through computer modeling. Unfortunately, our understanding of protein structure and the mechanisms of cross-seeding are not currently sufficient to make in silico prediction possible. Similarly, exploring opportunities for MM by searching for homologous sequences is no longer adequate: secondary and tertiary structures need to be considered as well. Investigation of the mechanisms proposed above is limited by the lack of knowledge of which bacterial amyloid proteins may be involved. Preliminary studies are underway to assess the role of the microbiota on protein folding and inflammation in animals and humans.

The concepts discussed here have significant translational potential. Therapeutic options include antibiotics to remove harmful bacteria, prebiotics to enhance the growth of desired organisms, and probiotics to provide desired bacteria. Diet is clearly important as well. In particular, the importance of diversity of diet leading to diversity of the microbiota is a new concept, which is clinically important $[45,123]$. Therapies to alter the amyloids produced by bacteria, or decrease their production, may also be developed [124]. It may also be possible to work on modifying the response of the immune system to the microbiota. 


\section{NOTE ADDED IN PROOF}

An additional route by which luminal proteins can influence the autonomic nervous system has recently been reported. Enteroendocrine cells of the gut epithelium were found to be in direct contact with mucosal neurons via a cytoplasmic process (Bohórquez DV, Shahid RA, Erdmann A, Kreger AM, Wang Y, Calakos N, Wang F, Liddle RA (2015) Neuroepithelial circuit formed by innervation of sensory enteroendocrine cells. J Clin Invest Jan 2. pii: 78361 doi:10.1172/JCI78361).

\section{ACKNOWLEDGMENTS}

Supported in part by the Michael J. Fox Foundation and the University of Louisville. The author is grateful to Drs. D. Demuth, K. LaFaver, P. O’Toole, R. Raha Chowdhury, A. Roberts, and V. Stribinskis for helpful comments and discussions. The author is also grateful to S. Nandi and J. Roberts for assistance.

The author's disclosure is available online (http://jalz.com/manuscript-disclosures/14-2841r1).

\section{REFERENCES}

[1] Bates HW (1861) Contributions to an insect fauna of the Amazon valley. Lepidoptera: Heliconidae. Trans Linnean Soc London 23, 495-566.

[2] Damian RT (1997) Parasite immune evasion and exploitation: Reflections and projections. Parasitology 115(Suppl), S169-S175.

[3] Lousberg EL, Diener KR, Brown MP, Hayball JD (2011) Innate immune recognition of poxviral vaccine vectors. Expert Rev Vaccines 10, 1435-1449.

[4] Friedland RP, Tedesco JM, Wilson AC, Atwood CS, Smith MA, Perry G, Zagorski MG (2008) Antibodies to potato virus $\mathrm{Y}$ bind the amyloid beta peptide: Immunohistochemical and NMR studies. J Biol Chem 283, 22550-22556.

[5] Liu R, Vaishnav RA, Roberts AM, Friedland RP (2013) Humans have antibodies against a plant virus: Evidence from tobacco mosaic virus. PLoS One 8, e60621.

[6] Liu R, Vaishnav RA, Roberts AM, Friedland RP (2014) Parkinson disease, edible Solanaceae, and tobacco mosaic virus. Ann Neurol 75, 162-163.

[7] Vaishnav RA, Liu R, Chapman J, Roberts AM, Ye H, Rebolledo-Mendez JD, Tabira T, Fitzpatrick AH, Achiron A, Running MP, Friedland RP (2013) Aquaporin 4 molecular mimicry and implications for neuromyelitis optica. J Neuroimmunol 260, 92-98.

[8] Rebolledo-Mendez JD, Vaishnav RA, Cooper NG, Friedland RP (2013) Cross-kingdom sequence similarities between human micro-RNAs and plant viruses. Commun Integr Biol 6, e24951.

[9] Guilherme L, Kalil J, Cunningham M (2006) Molecular mimicry in the autoimmune pathogenesis of rheumatic heart disease. Autoimmunity 39, 31-39.
[10] Oldstone MB (2014) Molecular mimicry: Its evolution from concept to mechanism as a cause of autoimmune diseases. Monoclon Antib Immunodiagn Immunother 33, 158-165.

[11] Schenk D, Barbour R, Dunn W, Gordon G, Grajeda H, Guido T, Hu K, Huang J, Johnson-Wood K, Khan K, Kholodenko D, Lee M, Liao Z, Lieberburg I, Motter R, Mutter L, Soriano F, Shopp G, Vasquez N, Vandevert C, Walker S, Wogulis M, Yednock T, Games D, Seubert P (1999) Immunization with amyloid-beta attenuates Alzheimer-disease-like pathology in the PDAPP mouse. Nature 400, 173-177.

[12] Gustaw KA, Garrett MR, Lee HG, Castellani RJ, Zagorski MG, Prakasam A, Siedlak SL, Zhu X, Perry G, Petersen RB, Friedland RP, Smith MA (2008) Antigen-antibody dissociation in Alzheimer disease: A novel approach to diagnosis. J Neurochem 106, 1350-1356.

[13] Nishiyama Y, Taguchi H, Hara M, Planque SA, Mitsuda Y, Paul S (2014) Metal-dependent amyloid beta-degrading catalytic antibody construct. J Biotechnol 180, 17-22.

[14] Colson P, Richet H, Desnues C, Balique F, Moal V, Grob JJ, Berbis P, Lecoq H, Harle JR, Berland Y, Raoult D (2010) Pepper mild mottle virus, a plant virus associated with specific immune responses, Fever, abdominal pains, and pruritus in humans. PLoS One 5, e10041.

[15] Colussi TM, Costantino DA, Hammond JA, Ruehle GM, Nix JC, Kieft JS (2014) The structural basis of transfer RNA mimicry and conformational plasticity by a viral RNA. Nature 511, 366-369.

[16] Reijerkerk A, Lopez-Ramirez MA, van Het Hof B, Drexhage JA, Kamphuis WW, Kooij G, Vos JB, van der Pouw Kraan TC, van Zonneveld AJ, Horrevoets AJ, Prat A, Romero IA, de Vries HE (2013) MicroRNAs regulate human brain endothelial cell-barrier function in inflammation: Implications for multiple sclerosis. J Neurosci 33, 6857-6863.

[17] Cazalla D, Yario T, Steitz JA (2010) Down-regulation of a host microRNA by a Herpesvirus saimiri noncoding RNA. Science 328, 1563-1566.

[18] Libri V, Helwak A, Miesen P, Santhakumar D, Borger JG, Kudla G, Grey F, Tollervey D, Buck AH (2012) Murine cytomegalovirus encodes a miR-27 inhibitor disguised as a target. Proc Natl Acad Sci U S A 109, 279-284.

[19] Zhang L, Hou D, Chen X, Li D, Zhu L, Zhang Y, Li J, Bian Z, Liang X, Cai X, Yin Y, Wang C, Zhang T, Zhu D, Zhang D, Xu J, Chen Q, Ba Y, Liu J, Wang Q, Chen J, Wang J, Wang M, Zhang Q, Zhang J, Zen K, Zhang CY (2012) Exogenous plant MIR168a specifically targets mammalian LDLRAP1: Evidence of cross-kingdom regulation by microRNA. Cell Res 22, 107-126.

[20] Desplats P, Lee HJ, Bae EJ, Patrick C, Rockenstein E, Crews L, Spencer B, Masliah E, Lee SJ (2009) Inclusion formation and neuronal cell death through neuron-to-neuron transmission of alpha-synuclein. Proc Natl Acad Sci U S A 106, 13010-13015.

[21] Masuda-Suzukake M, Nonaka T, Hosokawa M, Oikawa T, Arai T, Akiyama H, Mann DM, Hasegawa M (2013) Prionlike spreading of pathological alpha-synuclein in brain. Brain 136, 1128-1138.

[22] Guo JL, Lee VM (2011) Seeding of normal tau by pathological tau conformers drives pathogenesis of Alzheimer-like tangles. J Biol Chem 286, 15317-15331.

[23] Jucker M, Walker LC (2013) Self-propagation of pathogenic protein aggregates in neurodegenerative diseases. Nature 501, 45-51.

[24] Braak H, Del Tredici K (2008) Invited Article: Nervous system pathology in sporadic Parkinson disease. Neurology 70, 1916-1925. 
[25] Braak H, Del Tredici K, Rub U, de Vos RA, Jansen Steur EN, Braak E (2003) Staging of brain pathology related to sporadic Parkinson's disease. Neurobiol Aging 24, 197-211.

[26] Shults CW (2006) Lewy bodies. Proc Natl Acad Sci U S A 103, 1661-1668.

[27] Cushman M, Johnson BS, King OD, Gitler AD, Shorter J (2010) Prion-like disorders: Blurring the divide between transmissibility and infectivity. J Cell Sci 123, 1191-1201.

[28] Walker LC, Jucker M (2011) Amyloid by default. Nat Neurosci 14, 669-670.

[29] Ahmed Z, Cooper J, Murray TK, Garn K, McNaughton E, Clarke H, Parhizkar S, Ward MA, Cavallini A, Jackson S, Bose S, Clavaguera F, Tolnay M, Lavenir I, Goedert M, Hutton ML, O’Neill MJ (2014) A novel in vivo model of tau propagation with rapid and progressive neurofibrillary tangle pathology: The pattern of spread is determined by connectivity, not proximity. Acta Neuropathol 127, 667-683.

[30] Kovacs GG, Breydo L, Green R, Kis V, Puska G, Lorincz P, Perju-Dumbrava L, Giera R, Pirker W, Lutz M, Lachmann I, Budka H, Uversky VN, Molnar K, Laszlo L (2014) Intracellular processing of disease-associated alpha-synuclein in the human brain suggests prion-like cell-to-cell spread. $\mathrm{Neu}$ robiol Dis 69C, 76-92.

[31] Song HL, Shim S, Kim DH, Won SH, Joo S, Kim S, Jeon NL, Yoon SY (2014) beta-Amyloid is transmitted via neuronal connections along axonal membranes. Ann Neurol 75, 88-97.

[32] Prusiner SB (2012) Cell biology. A unifying role for prions in neurodegenerative diseases. Science 336, 1511-1513.

[33] van Keulen LJ, Vromans ME, van Zijderveld FG (2002) Early and late pathogenesis of natural scrapie infection in sheep. APMIS 110, 23-32.

[34] Attems J, Walker L, Jellinger KA (2014) Olfactory bulb involvement in neurodegenerative diseases. Acta Neuropathol 127, 459-475.

[35] Haehner A, Hummel T, Reichmann H (2011) Olfactory loss in Parkinson's disease. Parkinsons Dis 2011, 450939.

[36] Ubeda-Bañon I, Saiz-Sanchez D, de la Rosa-Prieto C, Martinez-Marcos A (2014) alpha-Synuclein in the olfactory system in Parkinson's disease: Role of neural connections on spreading pathology. Brain Struct Funct 219, 1513-1526.

[37] Hawkes CH, Del Tredici K, Braak H (2009) Parkinson's disease: The dual hit theory revisited. Ann N Y Acad Sci 1170, 615-622.

[38] Orru CD, Bongianni M, Tonoli G, Ferrari S, Hughson AG, Groveman BR, Fiorini M, Pocchiari M, Monaco S, Caughey B, Zanusso G (2014) A test for Creutzfeldt-Jakob disease using nasal brushings. N Engl J Med 371, 519-529.

[39] Human Microbiome Project, Consortium (2012) Structure, function and diversity of the healthy human microbiome. Nature 486, 207-214.

[40] Gordon JI (2012) Honor thy gut symbionts redux. Science 336, 1251-1253.

[41] Nicholson JK, Holmes E, Kinross J, Burcelin R, Gibson G, Jia W, Pettersson S (2012) Host-gut microbiota metabolic interactions. Science 336, 1262-1267.

[42] Scott KP, Gratz SW, Sheridan PO, Flint HJ, Duncan SH (2013) The influence of diet on the gut microbiota. Pharmacol Res 69, 52-60.

[43] Heintz C, Mair W (2014) You are what you host: Microbiome modulation of the aging process. Cell 156, 408-411.

[44] Hooper LV, Littman DR, Macpherson AJ (2012) Interactions between the microbiota and the immune system. Science 336, 1268-1273.
[45] Claesson MJ, Jeffery IB, Conde S, Power SE, O'Connor EM, Cusack S, Harris HM, Coakley M, Lakshminarayanan B, O'Sullivan O, Fitzgerald GF, Deane J, O'Connor M, Harnedy N, O'Connor K, O'Mahony D, van Sinderen D, Wallace M, Brennan L, Stanton C, Marchesi JR, Fitzgerald AP, Shanahan F, Hill C, Ross RP, O'Toole PW (2012) Gut microbiota composition correlates with diet and health in the elderly. Nature 488, 178-184.

[46] Hufnagel DA, Tukel C, Chapman MR (2013) Disease to dirt: The biology of microbial amyloids. PLoS Pathog $\mathbf{9}$, e1003740.

[47] Schwartz K, Boles BR (2013) Microbial amyloidsfunctions and interactions within the host. Curr Opin Microbiol 16, 93-99.

[48] Oli MW, Otoo HN, Crowley PJ, Heim KP, Nascimento MM, Ramsook CB, Lipke PN, Brady LJ (2012) Functional amyloid formation by Streptococcus mutans. Microbiology $\mathbf{1 5 8}$, 2903-2916.

[49] Bednarska NG, Schymkowitz J, Rousseau F, Van Eldere J (2013) Protein aggregation in bacteria: The thin boundary between functionality and toxicity. Microbiology 159, 17951806.

[50] Soto C (2012) Transmissible proteins: Expanding the prion heresy. Cell 149, 968-977.

[51] Pavlopoulos E, Trifilieff P, Chevaleyre V, Fioriti L, Zairis S, Pagano A, Malleret G, Kandel ER (2011) Neuralized1 activates CPEB3: A function for nonproteolytic ubiquitin in synaptic plasticity and memory storage. Cell 147, 13691383.

[52] Bokranz W, Wang X, Tschape H, Romling U (2005) Expression of cellulose and curli fimbriae by Escherichia coli isolated from the gastrointestinal tract. J Med Microbiol 54, 1171-1182.

[53] Cherny I, Rockah L, Levy-Nissenbaum O, Gophna U, Ron EZ, Gazit E (2005) The formation of Escherichia coli curli amyloid fibrils is mediated by prion-like peptide repeats. $J$ Mol Biol 352, 245-252.

[54] Bhattacharjee S, Lukiw WJ (2013) Alzheimer's disease and the microbiome. Front Cell Neurosci 7, 153.

[55] Nakano K, Hokamura K, Taniguchi N, Wada K, Kudo C, Nomura R, Kojima A, Naka S, Muranaka Y, Thura M, Nakajima A, Masuda K, Nakagawa I, Speziale P, Shimada N, Amano A, Kamisaki Y, Tanaka T, Umemura K, Ooshima $\mathrm{T}$ (2011) The collagen-binding protein of Streptococcus mutans is involved in haemorrhagic stroke. Nat Commun 2,485 .

[56] Solomon A, Richey T, Murphy CL, Weiss DT, Wall JS, Westermark GT, Westermark P (2007) Amyloidogenic potential of foie gras. Proc Natl Acad Sci U S A 104, 10998-11001.

[57] Xing Y, Nakamura A, Chiba T, Kogishi K, Matsushita T, Li F, Guo Z, Hosokawa M, Mori M, Higuchi K (2001) Transmission of mouse senile amyloidosis. Lab Invest $\mathbf{8 1}$, 493-499.

[58] Mabbott NA, Donaldson DS, Ohno H, Williams IR, Mahajan A (2013) Microfold (M) cells: Important immunosurveillance posts in the intestinal epithelium. Mucosal Immunol 6, 666-677.

[59] O'Hara AM, Shanahan F (2006) The gut flora as a forgotten organ. EMBO Rep 7, 688-693.

[60] Kujala P, Raymond CR, Romeijn M, Godsave SF, van Kasteren SI, Wille H, Prusiner SB, Mabbott NA, Peters PJ (2011) Prion uptake in the gut: Identification of the first uptake and replication sites. PLoS Pathog 7, e1002449.

[61] Little CS, Hammond CJ, MacIntyre A, Balin BJ, Appelt DM (2004) Chlamydia pneumoniae induces Alzheimer-like 
amyloid plaques in brains of BALB/c mice. Neurobiol Aging 25, 419-429.

[62] Leung JY, Chapman JA, Harris JA, Hale D, Chung RS, West AK, Chuah MI (2008) Olfactory ensheathing cells are attracted to, and can endocytose, bacteria. Cell Mol Life Sci 65, 2732-2739

[63] Panni P, Ferguson IA, Beacham I, Mackay-Sim A, Ekberg JA, St John JA (2013) Phagocytosis of bacteria by olfactory ensheathing cells and Schwann cells. Neurosci Lett 539, 65-70.

[64] Hartman K, Brender JR, Monde K, Ono A, Evans ML, Popovych N, Chapman MR, Ramamoorthy A (2013) Bacterial curli protein promotes the conversion of PAP248-286 into the amyloid SEVI: Cross-seeding of dissimilar amyloid sequences. PeerJ 1, e5.

[65] Morales R, Estrada LD, Diaz-Espinoza R, MoralesScheihing D, Jara MC, Castilla J, Soto C (2010) Molecular cross talk between misfolded proteins in animal models of Alzheimer's and prion diseases. J Neurosci 30, 4528-4535.

[66] Tanaka M, Chien P, Yonekura K, Weissman JS (2005) Mechanism of cross-species prion transmission: An infectious conformation compatible with two highly divergent yeast prion proteins. Cell 121, 49-62.

[67] Paravastu AK, Qahwash I, Leapman RD, Meredith SC, Tycko R (2009) Seeded growth of beta-amyloid fibrils from Alzheimer's brain-derived fibrils produces a distinct fibril structure. Proc Natl Acad Sci U S A 106, 7443-7448.

[68] Watts JC, Condello C, Stohr J, Oehler A, Lee J, DeArmond SJ, Lannfelt L, Ingelsson M, Giles K, Prusiner SB (2014) Serial propagation of distinct strains of Abeta prions from Alzheimer's disease patients. Proc Natl Acad Sci U S A 111, 10323-10328.

[69] Glabe CG (2004) Conformation-dependent antibodies target diseases of protein misfolding. Trends Biochem Sci $\mathbf{2 9}$, 542-547.

[70] Kayed R, Glabe CG (2006) Conformation-dependent anti-amyloid oligomer antibodies. Methods Enzymol 413, 326-344.

[71] Cui D, Kawano H, Hoshii Y, Liu Y, Ishihara T (2008) Acceleration of murine AA amyloid deposition by bovine amyloid fibrils and tissue homogenates. Amyloid 15, 77-83.

[72] Miglio A, Moscati L, Fruganti G, Pela M, Scoccia E, Valiani A, Maresca C (2013) Use of milk amyloid A in the diagnosis of subclinical mastitis in dairy ewes. J Dairy Res $\mathbf{8 0}$, 496-502.

[73] Villar-Pique A, Sabate R, Lopera O, Gibert J, Torne JM, Santos M, Ventura S (2010) Amyloid-like protein inclusions in tobacco transgenic plants. PLoS One 5, e13625.

[74] Lavelle EC, Murphy C, O'Neill LA, Creagh EM (2010) The role of TLRs, NLRs, and RLRs in mucosal innate immunity and homeostasis. Mucosal Immunol 3, 17-28.

[75] Atarashi K, Tanoue T, Oshima K, Suda W, Nagano Y, Nishikawa H, Fukuda S, Saito T, Narushima S, Hase K, Kim S, Fritz JV, Wilmes P, Ueha S, Matsushima K, Ohno H, Olle B, Sakaguchi S, Taniguchi T, Morita H, Hattori M, Honda K (2013) Treg induction by a rationally selected mixture of Clostridia strains from the human microbiota. Nature 500, 232-236.

[76] Lathrop SK, Bloom SM, Rao SM, Nutsch K, Lio CW, Santacruz N, Peterson DA, Stappenbeck TS, Hsieh CS (2011) Peripheral education of the immune system by colonic commensal microbiota. Nature 478, 250-254.

[77] Li J, Lee DS, Madrenas J (2013) Evolving bacterial envelopes and plasticity of TLR2-dependent responses:
Basic research and translational opportunities. Front Immunol 4, 347.

[78] Nishimori JH, Newman TN, Oppong GO, Rapsinski GJ, Yen JH, Biesecker SG, Wilson RP, Butler BP, Winter MG, Tsolis RM, Ganea D, Tukel C (2012) Microbial amyloids induce interleukin 17A (IL-17A) and IL-22 responses via Toll-like receptor 2 activation in the intestinal mucosa. Infect Immun 80, 4398-4408.

[79] Tukel C, Nishimori JH, Wilson RP, Winter MG, Keestra AM, van Putten JP, Baumler AJ (2010) Toll-like receptors 1 and 2 cooperatively mediate immune responses to curli, a common amyloid from enterobacterial biofilms. Cell Microbiol 12, 1495-1505.

[80] Czirr E, Wyss-Coray T (2012) The immunology of neurodegeneration. J Clin Invest 122, 1156-1163.

[81] Bechmann I, Priller J, Kovac A, Bontert M, Wehner T, Klett FF, Bohsung J, Stuschke M, Dirnagl U, Nitsch R (2001) Immune surveillance of mouse brain perivascular spaces by blood-borne macrophages. Eur J Neurosci 14, 1651-1658.

[82] Saresella M, Marventano I, Calabrese E, Piancone F, Rainone V, Gatti A, Alberoni M, Nemni R, Clerici M (2014) A complex proinflammatory role for peripheral monocytes in Alzheimer's disease. J Alzheimers Dis 38, 403-413.

[83] Trudler D, Farfara D, Frenkel D (2010) Toll-like receptors expression and signaling in glia cells in neuro-amyloidogenic diseases: Towards future therapeutic application. Mediators Inflamm 2010, pii: 497987.

[84] Palaga T, Buranaruk C, Rengpipat S, Fauq AH, Golde TE, Kaufmann SH, Osborne BA (2008) Notch signaling is activated by TLR stimulation and regulates macrophage functions. Eur J Immunol 38, 174-183.

[85] McGeer PL, McGeer EG (2002) Local neuroinflammation and the progression of Alzheimer's disease. J Neurovirol $\mathbf{8}$, 529-538.

[86] Akiyama H, Barger S, Barnum S, Bradt B, Bauer J, Cole GM, Cooper NR, Eikelenboom P, Emmerling M, Fiebich BL, Finch CE, Frautschy S, Griffin WS, Hampel H, Hull M, Landreth G, Lue L, Mrak R, Mackenzie IR, McGeer PL, O'Banion MK, Pachter J, Pasinetti G, Plata-Salaman C, Rogers J, Rydel R, Shen Y, Streit W, Strohmeyer R, Tooyoma I, Van Muiswinkel FL, Veerhuis R, Walker D, Webster S, Wegrzyniak B, Wenk G, Wyss-Coray T (2000) Inflammation and Alzheimer's disease. Neurobiol Aging 21, 383-421.

[87] Beraud D, Maguire-Zeiss KA (2012) Misfolded alphasynuclein and Toll-like receptors: Therapeutic targets for Parkinson's disease. Parkinsonism Relat Disord 18(Suppl 1), S17-S20.

[88] Richard KL, Filali M, Prefontaine P, Rivest S (2008) Tolllike receptor 2 acts as a natural innate immune receptor to clear amyloid beta 1-42 and delay the cognitive decline in a mouse model of Alzheimer's disease. J Neurosci 28, 57845793.

[89] Wlodarska M, Thaiss CA, Nowarski R, Henao-Mejia J, Zhang JP, Brown EM, Frankel G, Levy M, Katz MN, Philbrick WM, Elinav E, Finlay BB, Flavell RA (2014) NLRP6 inflammasome orchestrates the colonic host-microbial interface by regulating goblet cell mucus secretion. Cell 156, 1045-1059.

[90] Raby AC, Le Bouder E, Colmont C, Davies J, Richards P, Coles B, George CH, Jones SA, Brennan P, Topley N, Labeta MO (2009) Soluble TLR2 reduces inflammation without compromising bacterial clearance by disrupting TLR2 triggering. J Immunol 183, 506-517. 
[91] Rapsinski GJ, Newman TN, Oppong GO, van Putten JP, Tukel C (2013) CD14 protein acts as an adaptor molecule for the immune recognition of Salmonella curli fibers. $J$ Biol Chem 288, 14178-14188.

[92] Perry VH, Holmes C (2014) Microglial priming in neurodegenerative disease. Nat Rev Neurol 10, 217-224.

[93] Bodea LG, Wang Y, Linnartz-Gerlach B, Kopatz J, Sinkkonen L, Musgrove R, Kaoma T, Muller A, Vallar L, Di Monte DA, Balling R, Neumann H (2014) Neurodegeneration by activation of the microglial complement-phagosome pathway. J Neurosci 34, 8546-8556.

[94] Yan SD, Yan SF, Chen X, Fu J, Chen M, Kuppusamy P, Smith MA, Perry G, Godman GC, Nawroth P, et al. (1995) Non-enzymatically glycated tau in Alzheimer's disease induces neuronal oxidant stress resulting in cytokine gene expression and release of amyloid beta-peptide. Nat Med $\mathbf{1}$, 693-699.

[95] Smith MA, Perry G, Richey PL, Sayre LM, Anderson VE, Beal MF, Kowall N (1996) Oxidative damage in Alzheimer's. Nature 382, 120-121.

[96] Rashid T, Wilson C, Ebringer A (2013) The link between ankylosing spondylitis, Crohn's disease, Klebsiella, and starch consumption. Clin Dev Immunol 2013, 872632.

[97] Benitez BA, Jin SC, Guerreiro R, Graham R, Lord J, Harold D, Sims R, Lambert JC, Gibbs JR, Bras J, Sassi C, Harari O, Bertelsen S, Lupton MK, Powell J, Bellenguez C, Brown K, Medway C, Haddick PC, van der Brug MP, Bhangale T, Ortmann W, Behrens T, Mayeux R, Pericak-Vance MA, Farrer LA, Schellenberg GD, Haines JL, Turton J, Braae A, Barber I, Fagan AM, Holtzman DM, Morris JC, Williams J, Kauwe JS, Amouyel P, Morgan K, Singleton A, Hardy J, Goate AM, Cruchaga C (2014) Missense variant in TREML2 protects against Alzheimer's disease. Neurobiol Aging 35, 1510 e1519-1526.

[98] Rayaprolu S, Mullen B, Baker M, Lynch T, Finger E, Seeley WW, Hatanpaa KJ, Lomen-Hoerth C, Kertesz A, Bigio EH, Lippa C, Josephs KA, Knopman DS, White CL, 3rd, Caselli R, Mackenzie IR, Miller BL, Boczarska-Jedynak M, Opala G, Krygowska-Wajs A, Barcikowska M, Younkin SG, Petersen RC, Ertekin-Taner N, Uitti RJ, Meschia JF, Boylan KB, Boeve BF, Graff-Radford NR, Wszolek ZK, Dickson DW, Rademakers R, Ross OA (2013) TREM2 in neurodegeneration: Evidence for association of the p. R47H variant with frontotemporal dementia and Parkinson's disease. $\mathrm{Mol}$ Neurodegener 8, 19.

[99] Verbrugghe P, Kujala P, Waelput W, Peters PJ, Cuvelier CA (2008) Clusterin in human gut-associated lymphoid tissue, tonsils, and adenoids: Localization to $\mathrm{M}$ cells and follicular dendritic cells. Histochem Cell Biol 129, 311-320.

[100] Carare RO, Teeling JL, Hawkes CA, Puntener U, Weller RO, Nicoll JA, Perry VH (2013) Immune complex formation impairs the elimination of solutes from the brain: Implications for immunotherapy in Alzheimer's disease. Acto Neuropathol Commun 1, 48

[101] Hawkes CA, Carare RO, Weller RO (2014) Amyloid and tau in the brain in sporadic Alzheimer's disease: Defining the chicken and the egg. Acta Neuropathol 127, 617-618.

[102] Savva GM, Wharton SB, Ince PG, Forster G, Matthews FE, Brayne C (2009) Age, neuropathology, and dementia. $N$ Engl J Med 360, 2302-2309.

[103] Holmes C (2013) Review: Systemic inflammation and Alzheimer's disease. Neuropathol Appl Neurobiol 39, 51-68.

[104] McGeer PL, McGeer EG (2013) The amyloid cascadeinflammatory hypothesis of Alzheimer disease: Implications for therapy. Acta Neuropathol 126, 479-497.
[105] Bernstein KE, Koronyo Y, Salumbides BC, Sheyn J, Pelissier L, Lopes DH, Shah KH, Bernstein EA, Fuchs DT, Yu JJ, Pham M, Black KL, Shen XZ, Fuchs S, KoronyoHamaoui M (2014) Angiotensin-converting enzyme overexpression in myelomonocytes prevents Alzheimer's-like cognitive decline. J Clin Invest 124, 1000-1012.

[106] Maier M, Peng Y, Jiang L, Seabrook TJ, Carroll MC, Lemere CA (2008) Complement C3 deficiency leads to accelerated amyloid beta plaque deposition and neurodegeneration and modulation of the microglia/macrophage phenotype in amyloid precursor protein transgenic mice. J Neurosci $\mathbf{2 8}$, 6333-6341.

[107] Monsonego A, Imitola J, Petrovic S, Zota V, Nemirovsky A, Baron R, Fisher Y, Owens T, Weiner HL (2006) Abeta-induced meningoencephalitis is IFN-gammadependent and is associated with $\mathrm{T}$ cell-dependent clearance of Abeta in a mouse model of Alzheimer's disease. Proc Natl Acad Sci U S A 103, 5048-5053.

[108] Butovsky O, Koronyo-Hamaoui M, Kunis G, Ophir E, Landa G, Cohen H, Schwartz M (2006) Glatiramer acetate fights against Alzheimer's disease by inducing dendritic-like microglia expressing insulin-like growth factor 1. Proc Natl Acad Sci U S A 103, 11784-11789.

[109] Aguzzi A (2014) Neurodegeneration: Alzheimer's disease under strain. Nature 512, 32-34.

[110] Bagriantsev S, Liebman S (2006) Modulation of Abeta42 low-n oligomerization using a novel yeast reporter system. BMC Biol 4, 32

[111] Tsuang D, Leverenz JB, Lopez OL, Hamilton RL, Bennett DA, Schneider JA, Buchman AS, Larson EB, Crane PK, Kaye JA, Kramer P, Woltjer R, Trojanowski JQ, Weintraub D, Chen-Plotkin AS, Irwin DJ, Rick J, Schellenberg GD, Watson GS, Kukull W, Nelson PT, Jicha GA, Neltner JH, Galasko D, Masliah E, Quinn JF, Chung KA, Yearout D, Mata IF, Wan JY, Edwards KL, Montine TJ, Zabetian CP (2013) APOE epsilon4 increases risk for dementia in pure synucleinopathies. JAMA Neurol 70, 223-228.

[112] Fischer S, Dolu MH, Zundt B, Meyer G, Geisler S, Jungst D (2001) Apolipoprotein E polymorphism and lithogenic factors in gallbladder bile. Eur J Clin Invest 31, 789-795.

[113] Liu CC, Kanekiyo T, Xu H, Bu G (2013) Apolipoprotein E and Alzheimer disease: Risk, mechanisms and therapy. Nat Rev Neurol 9, 106-118.

[114] Urosevic N, Martins RN (2008) Infection and Alzheimer's disease: The APOE epsilon4 connection and lipid metabolism. J Alzheimers Dis 13, 421-435.

[115] Zotova E, Bharambe V, Cheaveau M, Morgan W, Holmes C, Harris S, Neal JW, Love S, Nicoll JA, Boche D (2013) Inflammatory components in human Alzheimer's disease and after active amyloid-beta42 immunization. Brain 136, 2677-2696.

[116] Mapstone M, Cheema AK, Fiandaca MS, Zhong X, Mhyre TR, MacArthur LH, Hall WJ, Fisher SG, Peterson DR, Haley JM, Nazar MD, Rich SA, Berlau DJ, Peltz CB, Tan MT, Kawas CH, Federoff HJ (2014) Plasma phospholipids identify antecedent memory impairment in older adults. Nat Med 20, 415-418.

[117] Kalaria RN, Maestre GE, Arizaga R, Friedland RP, Galasko D, Hall K, Luchsinger JA, Ogunniyi A, Perry EK, Potocnik F, Prince M, Stewart R, Wimo A, Zhang ZX, Antuono P, World Federation of Neurology Dementia Research G (2008) Alzheimer's disease and vascular dementia in developing countries: Prevalence, management, and risk factors. Lancet Neurol 7, 812-826. 
[118] Singh N, Gurav A, Sivaprakasam S, Brady E, Padia R, Shi H, Thangaraju M, Prasad PD, Manicassamy S, Munn DH, Lee JR, Offermanns S, Ganapathy V (2014) Activation of Gpr109a, receptor for niacin and the commensal metabolite butyrate, suppresses colonic inflammation and carcinogenesis. Immunity 40, 128-139.

[119] Satoh M, Ishikawa Y, Minami Y, Takahashi Y, Nakamura M (2008) Role of Toll like receptor signaling pathway in ischemic coronary artery disease. Front Biosci 13, 67086715.

[120] Kalaria RN, Ihara M (2013) Dementia: Vascular and neurodegenerative pathways-will they meet? Nat Rev Neurol $\mathbf{9}$, 487-488.

[121] Tang Q, Roan NR, Yamamura Y (2013) Seminal plasma and semen amyloids enhance cytomegalovirus infection in cell culture. J Virol 87, 12583-12591.
[122] Usmani SM, Zirafi O, Muller JA, Sandi-Monroy NL, Yadav JK, Meier C, Weil T, Roan NR, Greene WC, Walther P, Nilsson KP, Hammarstrom P, Wetzel R, Pilcher CD, Gagsteiger F, Fandrich M, Kirchhoff F, Munch J (2014) Direct visualization of HIV-enhancing endogenous amyloid fibrils in human semen. Nat Commun 5, 3508.

[123] Borre YE, O'Keeffe GW, Clarke G, Stanton C, Dinan TG, Cryan JF (2014) Microbiota and neurodevelopmental windows: Implications for brain disorders. Trends Mol Med 20, 509-518.

[124] Lloyd SJ, Ritchie JM, Torres AG (2012) Fimbriation and curliation in Escherichia coli O157:H7: A paradigm of intestinal and environmental colonization. Gut Microbes $\mathbf{3}$, 272-276. 